\title{
Miejskie (r)ewolucje. \\ Radykalizm retoryki a praktyka reformy
}

Artykuł podejmuje wątki związane z ideą prawa do miasta: traktuje ją jako jedną z naczelnych ideologii polityki emancypacyjnej, z drugiej strony wyraża zainteresowanie aktorami odwołującymi się (wprost i nie wprost) do jej retoryki. Analizuje prawo do miasta jako puste znaczące - kategorię, której sens nadają aktorzy wykorzystujący ją w ramach pragmatyki walk społecznych. Stara się też podjąć wątek „(r)ewolucyjnej retoryki” rozmaitych podmiotów zmiany społecznej, wskazując na fakt postępującej funkcjonalizacji idei prawa do miasta, która z ideologii (czy też doktryny praktycznej) o marksistowskiej, ergo rewolucyjnej proweniencji wykorzystywana jest coraz częściej jako polityczna etykieta.

Słowa kluczowe: prawo do miasta, ruchy społeczne, miejskie ruchy społeczne, marksizm, zmiana społeczna, rewolucja, reformizm. 
Hasło „prawa do miasta” czy proklamacja „miejskiej rewolucji” stały się jednymi z najczęstszych sloganów pozaparlamentarnej polityki we współczesnej Polsce. Nawiązując do nich, chcę rozpatrzyć poniżej przede wszystkim dwa wątki: z jednej strony krótko przedstawię rozmaite sposoby rozumienia „prawa do miasta” - tego, jak ewoluowało dzięki „obróbce teoretycznej” w rękach rozmaitych badaczy, z drugiej, skupię się na „pożytkach z pojęcia”, jakie czerpią rozmaici aktorzy społeczni (przede wszystkim tak zwane „miejskie ruchy społeczne”), którzy się doń odwołują ${ }^{1}$.

Interesować mnie będzie dość niejednoznaczna retoryka i „logika działań” ruchów miejskich, w szczególności napięcie między marksowsko-engelsowską i konfliktowo (ergo antykapitalistycznie) zorientowaną genezą idei „prawa do miasta”2, do której się odwołują, a jej funkcjonalizacją, napięcie między radykalizmem retoryki („miejska rewolucja”) i reformistyczną praxis (części) środowisk związanych z ruchami miejskimi. Zastanawiające jest bowiem, czy pojęcie „rewolucji” ${ }^{3}$ nie jest tu li tylko zgrabną i ponętną figurą retoryczną? Jak bardzo określone ruchy miejskie przywołują postulat „rewolucjonizowania” rzeczywistości, na ile wreszcie ich krytyka instytucji społecznych jest głęboka i w istocie „rewolucyjna”?

1 Chcę na samym początku podkreślić, że podejmowana tu próba ma charakter przede wszystkim heurystyczny. Artykuł nie jest sprawozdaniem ze zrealizowanych badań empirycznych, stanowi natomiast jeden z kroków przygotowujących takowe badania i wskazuje kilka spośród wielu problemów, jakie zostaną w nich podjęte. Nie oznacza to jednak, że ma charakter spekulatywny, zaś podejmując próbę dokonywania uogólnień, jest pozbawiony odniesień empirycznych. Jest bowiem efektem długotrwałego „zwiadu badawczego”. Opiera się między innymi na: obserwacji głównych kierunków działania tak zwanych miejkich ruchów społecznych oraz bezpośrednich kontaktach z reprezentantami tych środowisk z Poznania, Wrocławia, Warszawy, Krakowa i Trójmiasta; udziale w I i III Kongresie Ruchów Miejskich (KRM) oraz monitorowaniu osiagnięć II KRM; obserwacji działań podejmowanych przez miejskich aktywistów; wreszcie, śledzeniu debat, które inicjuje i w których uczestniczy interesujące mnie środowisko. Ramy czasowe działania ruchów miejskich w Polsce są problematyczne. Pierwsze ruchy, które zaczęły autodefinicyjnie określać się jako miejskie, pojawiły się w roku 2007. Jeżeli jednak założymy, że silną ,zgodność sensową” z ideą prawa do miasta wypracowały już wcześniej ruchy neoanarchistyczne, cezura przesunie się do końca wieku dwudziestego. Wówczas perspektywa czasowa będzie obejmowała około 15 lat.

2 Mówiąc o marksistowskich korzeniach idei „prawa do miasta”, warto pamiętać, że Marks pozostawił w zasadzie to pole badawcze Engelsowi, co odnotowano w literaturze przedmiotu; zob. np. A. Merrifield, Metromarxism: A Marxist Tale of the City, New York-London 2002, s. 7; P. Pluciński, Metroengelsizm, czyli o Engelsowskich korzeniach krytycznych badań nad miastem, „Nowa Krytyka” 2012, nr 28, s. 103-121.

3 Zob. m.in. L. Mergler, K. Pobłocki, Nadchodzaca rewolucja miejska, „Le Monde Diplomatique" 2010, nr 9.

4 Żaden z polskich ruchów miejskich nie odwołuje się w sposób otwarty do mar- 


\section{„Prawo do miasta” jako „puste znaczące”? \\ Od Engelsa do Harveya ${ }^{5}$}

Lefebvre’owska idea „prawa do miasta”, cztery i pół dekady po ogłoszeniu Le Droit ŕ la ville, przeżywa dziś swoją drugą młodość, jest jednym z najbardziej żywotnych postulatów politycznych, wypisanych na sztandarach „miejskich rewolucjonistów”. Co więcej, jest dziś - bardziej niż kiedykolwiek dotąd - politycznym sloganem, z przynależnym mu bagażem polisemiczności. Innymi słowy, ukrywają się za nim bardzo różnorodne postulaty, w zależności od kontekstu, w którym jest przywoływane,oraz użytkownika, który się nim posługuje. „Prawo do miasta" jako żądanie polityczne stało się kolejnym pustym znaczącym $^{6}$ (Laclau), kategorią otwartą na rozmaitość różnorodnych

ksistowskich korzeni idei prawa do miasta i do jej rewolucyjnego potencjału, zaś postulat powrotu do „czytania Marksa” w kontekście definiowania tego, czym są „problemy miejskie", traktowany jest na ogół ze sporą podejrzliwością (choćby w kwestii skuteczności strategii politycznych inkorporujących otwarcie marksistowską siatkę analityczna), niekiedy pobłażliwością, czasem niechęcią. Nie przeszkadza to jednak przywoływaniu interesującej nas kategorii prawa do miasta jako chwytliwego wykrzyknienia, swoistej „marki” (Zob. Jaki bunt? Jakich miast?, „Przekrój”, 2012, nr 32/33, s. 8-12). Za zwrócenie uwagi na zasadność uwypuklenia tej kwestii dziękuję Krystianowi Szadkowskiemu. Trzeba tu jednak poczynić jeszcze jedną uwagę dotyczącą aktywności ruchów neoanarchistycznych, których retoryka jest silnie antysystemowa i definiująca „kwestię miejską” w kategoriach stosunków własności (co jest zbieżne z pierwotnym pojmowaniem idei prawa do miasta jako idei krytycznej). Nie korzystają one jednak z kategorii „prawa do miasta” jako etykiety opatrującej swoją aktywność. Problem ten będzie przywołany szerzej w dalszej części artykułu.

5 Przywołana tu narracja na temat historyczno-dyskursywnej zmienności idei „prawa do miasta” ma oczywiście charakter uproszczony - pomijam tu wiele kontekstów oraz szczegółowe omówienie poglądów licznych badaczy, spośród których wymienić należałoby choćby: Susan Fainstein (Urban Political Movements: The Search for Power by Minority Groups in American Cities, New Jersey 1974; The Just City, London 2010), Petera Marcuse'a, Neila Brennera i Margit Mayer, (Cities for People, Not for Profit: Critical Urban Theory and ther Right to the City, New YorkLondon 2011), Dona Mitchella (The Right to the City: Social Justice and the Fight for Public Space, New York-London 2003), Marka Purcella (Recapturing Democracy: Neoliberalization and the Struggle for Alternative Urban Futures, New York-London 2008), Edwarda W. Soję (Seeking Spatial Justice, Minneapolis-London 2010), Neila Smitha (The New Urban Frontier: Gentrification and the Revanchist City, London-New York 2005) czy Marcelo Lopesa de Souzę (Which Right to Which City?: In Defence of Political-Strategic Clarity, "Interface: A Journal For and About Social Movements" 2010, vol. 2(1), s. 315-333).

6 Sama kategoria „prawa do miasta” stała się więc, w toku swojego historycznej ewolucji pojęciowej, swoistym asamblażem - zbiorem znaczeń nadbudowywanych, częściowo w związku ze zmiennością społeczno-historycznego kontekstu 
artykulacji, przekształcającą się - w zależności od kontekstu - w zaplecze ideologiczne w ramach przygodnych walk społecznych ${ }^{7}$. Wreszcie, kategorią zależną od tego, kto puste znaczące wypełnia treścią. Wynika to po części z „otwartości”, jaką wpisał w swoje żądanie „prawa do miasta” sam Henri Lefebvre ${ }^{8}$.

Ideę „prawa do miasta”, jakkolwiek kojarzymy ją współcześnie przede wszystkim z tym ostatnim, wywieść możemy z klasycznych badań Fryderyka Engelsa nad warunkami życia angielskich robotników ${ }^{9}$ oraz procesami relokacji niechcianych klas społecznych (dziś powiedzielibyśmy: gentryfikacji) z centrum Paryża w efekcie jego haussmannizacji ${ }^{10}$. Co więcej, w zgodzie z paradygmatem konfliktowym, szczególnie marksistowskiej proweniencji, Engels konkluduje (oczywiście, nie używając tego pojęcia), że „prawo do miasta” odzyskać można wyłącznie poza kapitalizmem, czyli po zniesieniu jego panowania. „Walka o miasto” pojmowana była tutaj jako walka rewolucyjna, zaś rewolucja społeczna to m.in. przekształcenie stosunków produkcji, ergo stosunków własnościowych. Innymi słowy - działanie rewolucyjne, którego podmiotem miała być oczywiście klasa robotnicza, zakłada implicite konieczność redefinicji stosunków własności i warunkujących własność, a w konsekwencji również stosunków społecznych przez własność warunkowanych ${ }^{11}$.

Ten sam motyw podkreślał Lefebvre, nacisk kładąc na poszukiwanie „innego” miasta (niż to, które znamy) w „odmiennej”, ergo pozakapitalistycznej, rzeczywistości ${ }^{12}$. Analiza Lefebvre’a była silnie „ukla-

działania, przez poszczególnych badaczy posługujących się tą kategorią. Poprzez to stała się bardzo polisemiczna, w pewnej mierze też performatywna - jej sens (niekoniecznie tożsamy z Engelsowskimi konfliktowymi źródłami) definiują bowiem same podmioty miejskiej polityki.

7 Pisze o tym otwarcie również David Harvey w swoim Buncie miast: „Prawo do miasta jest pustym znaczącym pełnym immanentnych, ale nie transcendentnych właściwości. Nie oznacza to, że jest nieważne i politycznie bezsilne; wszystko zależy od tego, komu uda się napełnić owo znaczące rewolucyjnym, przeciwstawnym reformistycznemu, znaczeniem" (D. Harvey, Bunt miast: Prawo do miasta i miejska rewolucja, tłum. Praktyka Teoretyczna, Warszawa 2012, s. 186-187).

8 H. Lefebvre, Prawo do miasta, tłum. E. Majewska, współpraca Ł. Stanek, „Praktyka Teoretyczna” 2012, nr 5, http://www.praktykateoretyczna.pl/PT_nr5_2012_Logika_sensu/14.Lefebvre.pdf.

9 F. Engels, Potożenie klasy robotniczej $w$ Anglii, w: K. Marks, F. Engels, Dzieta, t. 2, Warszawa 1979.

10 Tegoż, W kwestii mieszkaniowej, w: K. Marks, F. Engels, Dzieta, t. 18, Warszawa 1969, s. 289.

11 Zob. St. Kozyr-Kowalski, Socjologia, spoteczeństwo obywatelskie i państwo, Poznań 1999.

12 H. Lefebvre, Burżuazja i przestrzeń, w: Krytyka spoteczeństwa kapitali- 
sowiona”: wskazywał on na „deterioryzację” współczesnej burżuazji, uprzedmiotowienie i utowarowienie siły roboczej w ramach modernistycznego modelu miasta-fabryki i miasta-przestrzeni oraz wskazywał, że podmiotem "miejskiej rewolucji” (ex definitione antykapitalistycznej) będzie klasa robotnicza.

W porównaniu z Engelsowską wizją „rewolucji własnościowej” Lefebvre'owska idea prawa do miasta okazała się bardziej otwarta. W dużej mierze dzięki związkom z sytuacjonistami, autor Le Droit ŕ la ville swoje materialistyczne analizy uzupełniał o „moment subiektywistyczny”. Miasto jawi się w jego wpadku jako „królestwo wolności”, wręcz „królestwo wyobraźni” - przestrzeń nieskrępowanej ekspresji, nieutowarowionej wymiany, spontaniczności przeżyć i spotkań w przestrzeni, które składają się na „życie po miejsku” ${ }^{13}$. Idea prawa do miasta i samo miasto mają być swoistą soczewką, skupiającą w sobie całość (ouvre) ludzkiego doświadczenia, niesprowadzalną do jakichś partykularnych, wycinkowych kontekstów. Owa totalność żądania „prawa do miasta” zawiera też jednak w sobie całkiem silny pierwiastek „postromantyczny”, czerpiący jeszcze z francuskiego symbolizmu. To wszak Rimbaudowskie il faut changer la vie Debord przekształcił w wezwanie: „musimy zmienić nasze życie”, z kolei dorobek sytuacjonistów jest nie do przecenienia w kontekście finalnego kształtu myśli Lefebvre’a ${ }^{14}$. Przełożył on bowiem to, czego pragnęli i Rimbaud, i Debord, na język „eksperymentalnej utopii” - miasta wytwarzanego w społecznym działaniu i w opozycji wobec miasta-obiektu konsumpcji. Wreszcie sam Lefebvre (jako krytyk urbanistycznej koncepcji „strefowania”) oraz związane z nim kręgi intelektualne lokowali się w bezpośredniej opozycji wobec funkcjonalizmu i modernizmu, występując przede wszystkim przeciwko jego hiperracjonalności, postulując w efekcie antytechnokratyczne, „społeczne wytwarzanie przestrzeni”.

Wystąpienie Lefebvre'a wywołało szeroki rezonans, skutkując coraz szerszym zainteresowaniem ideą prawa do miasta oraz zdefiniowaniem „kwestii miejskiej” jako jednej z naczelnych sfer, w których działa dynamika późnego kapitalizmu. Nie bez znaczenia był tu fakt, że idea

stycznego w pracach socjologów zachodnich, wybór B. Jałowiecki, St. Nurek, Katowice 1979; tegoż, Burżuazja i przestrzeń, w: Krytyka spoteczeństwa kapitalistycznego w pracach socjologów zachodnich, wybór B. Jałowiecki, St. Nurek, Katowice 1979.

13 H. Lefebvre, Prawo do miasta, s. 184.

$14 \mathrm{O}$ wzajemnych relacjach między Lefebvrem a sytuacjonistami zob. m.in. T. McDonough, The Situationists and the City, London 2009 lub A. Jappe, Guy Debord, tłum. D. Nicholson-Smith, Berkeley 1999 (zwłaszcza rozdział 2: The Practice of Theory, s. 72-81). 
prawa do miasta stała się żądaniem politycznym właśnie na fali erupcji kontrkultury ${ }^{15}$.

Jednym z najwybitniejszych reprezentantów interesującej nas tradycji intelektualnej jest Manuel Castells, który w odróżnieniu do Lefebvre’a, a w pewnej mierze pod wpływem Alaina Touraine’a, punkt ciężkości przeniósł w stronę empirii, skupiając się na działalności miejskich ruchów społecznych ${ }^{16}$ oraz definiując „prawo do miasta” w kategoriach „konsumpcji zbiorowej” ${ }^{17}$. Ta ostatnia to w jego rozumieniu przede wszystkim dobra i usługi publiczne, do których realny dostęp jest nieegalitarny i związany z usytuowaniem klasowym, co z kolei jest jedną z głównych przyczyn konfliktów społecznych w mieście. Co istotne - to właśnie u hiszpańskiego socjologa najsilniej zaznacza się ważne przejście. Na pierwszy rzut oka młody Castells prezentuje marksistowski ekonomizm - mówi bowiem przede wszystkim o nieegalitarnej dystrybucji dóbr i ułatwień, wskazując na ich klasowy charakter, postulując egalitaryzację dostępu do dóbr i usług konsumpcji zbiorowej. Środki nacisku mają tu jednak charakter stricte polityczny (za sprawą oddolnych ruchów społecznych), zaś definiowany przez Castellsa horyzont zmiany społecznej mieści się wyraźnie w ramach korekty kapitalizmu (jego „uspołecznianiu” ). Horyzont zmiany społecznej projektowany jest więc w ramach nadbudowy, bez powszechnego żądania zmian fundamentów porządku społecznego ${ }^{18}$.

15 Zachodnioeuropejskie ruchy miejskie powstałe w latach sześćdziesiątych dwudziestego wieku i kojarzone z symbolicznym "majem '68” ulegały ostatecznie podobnym uwarunkowaniom strukturalnym i przeobrażeniom, co tak zwane „nowe ruchy społeczne”, zaś idea prawa do miasta okazała się w rękach rozmaitych podmiotów społecznych na przestrzeni czterech dekad „pomajowego” dziedzictwa niezwykle plastyczna; zob. M. Castells, Walka klas i sprzeczności miejskie: Pojawienie się spotecznych ruchów miejskich $w$ kapitalizmie monopolistycznym, tłum. B. Jałowiecki, P. Jałowiecki, w: Krytyka spoteczeństwa kapitalistycznego w pracach socjologów zachodnich, wybór B. Jałowiecki, St. Nurek, Katowice 1979.

16 M. Castells, Kwestia miejska, tłum. B. Jałowiecki, J. Piątkowski, Warszawa 1982 (zwłaszcza część IV, rozdział 11: Teoretyczne narzędzia badania polityki miejskiej, s. 273-287 oraz 13: Badania nad spotecznymi ruchami miejskimi, s. 337-396).

17 Tamże, Postowie z 1975 roku, s. 420-431.

18 Bez mała dekadę później Castells jeszcze wyraźniej przesunie się w kierunku „kulturalizmu”. Zob. M. Castells, The City and the Grassroots: A CrossCultural Theory of Urban Social Movements, Berkeley-London 1983 (zwłaszcza rozdział 3: City and Culture: The San Francisco Experience, s. 97-172 oraz 6: The Cross-Cultural Theory of Urban Social Change, s. 289-336. Warto zwrócić uwagę również na krótką polemikę Davida Harveya z Castellsem: D. Harvey, Bunt miast, s. 177. 
Współcześnie najbardziej wpływowym interpretatorem i rzecznikiem idei prawa do miasta jest David Harvey, marksistowski geograf społeczny. Według Harveya

Prawo do miasta jest czymś o wiele szerszym niż prawo dostępu jednostki lub grupy do zasobów, które zawiera miasto: jest prawem do zmiany i wynajdowania miasta na nowo takim, jakim go pragniemy. Jest też, co więcej, prawem bardziej kolektywnym niż indywidualnym, ponieważ wynajdywanie miasta na nowo w sposób nieunikniony zależy od sprawowania kolektywnej władzy nad procesami urbanizacji. Wolność do tworzenia i przekształcania samych siebie i naszych miast jest, chcę to podkreślić, jednym z najcenniejszych i jednocześnie najbardziej lekceważonych pośród praw człowieka ${ }^{19}$.

Harvey łączy i autorsko interpretuje kilka przywołanych wcześniej wątków: mówi choćby o prawie korzystania z miejskich zasobów (u Castellsa byłaby to konsumpcja zbiorowa), podkreśla też jednak głęboko humanistyczny charakter relacji człowiek-miasto (Lefebvre), gdzie zmiana jest obustronna, człowiek podmiotowo kształtując miasto, kształtuje również siebie i innych (można by mówić tu o uruchamianiu procesów społecznego uczenia się). Dalej Harvey wpisuje „prawo do miasta” w ramy walki antykapitalistycznej, podobnie jak Lefebvre podkreślając jej klasowy charakter, jej kresu upatrując w ramach porządku postkapitalistycznego, przy założeniu, że przekształcenie to musiałoby mieć charakter rewolucyjny (Engels, Lefebvre). To jednak, jeśli można tak powiedzieć, Harvey-taktyk operujący w długiej perspektywie czasowej. Do tego jednak, w perspektywie krótkiego trwania, Harvey akceptuje strategie wyraźnie reformistyczne, szczególnie legalistyczne procedury działania. Przywołuje choćby przykład zwieńczonych sukcesem nacisków brazylijskich aktywistów miejskich, którzy doprowadzili do wpisania statutu miejskiego, czerpiącego z idei „prawa do miasta” do konstytucji ${ }^{20}$.

Harveyowska interpretacja idei prawa do miasta jest więc bardzo pojemna. Jest swoistym asamblażem, skupiając w sobie tropy obecne wcześniej u Engelsa, Lefebvre’a czy Castellsa, łącząc radykalny horyzont walki antykapitalistycznej oraz reformatorski pragmatyzm „długiego marszu przez instytucje” i walki „zagnieżdżonej w systemie”21. Co więcej, Harvey podnosi problem „prawa do miasta” w kontekście „praw człowieka”, otwierając tym samym coraz szerzej dyskutowaną kwestię uniwersalizmu samej koncepcji ${ }^{22}$.

19 D. Harvey, Bunt miast, s. 22.

20 Tamże, s. 39.

21 Tamże, s. 161-207.

22 Sam Harvey jest tu zresztą dość wieloznaczny: $\mathrm{z}$ jednej strony jest rzecz- 
To bardzo inkluzyjne

pojmowanie

omawianego

prawa doskonale

konweniuje z bardzo

zróżnicowanym,

czasem hybrydowym

charakterem miejskich

ruchów społecznych,

które wypełniają

puste znaczące „prawa

do miasta" stosownie

do taktycznego

zapotrzebowania
Stanowisko Harveya - przecież teoretyczno-metodologicznego marksisty - najlepiej chyba pokazuje prawo do miasta jako „puste znaczące”, silnie podyktowane pragmatyką protestu. Szkocki geograf, jako teoretyk i badacz trafnie definiuje sprzeczności współczesnego kapitalizmu, jednocześnie jako ideolog projektuje antykapitalistyczny (socjalistyczny?) horyzont ${ }^{23}$, na poziomie codziennych, pragmatycznych walk społecznych aprecjując przy tym „strategię małych kroków” i korekt nadbudowy istniejącego systemu, w ramach których postulat „prawa do miasta” jako walki o redefinicję instytucji własności jest zdecydowanie mniejszościowy.

To bardzo inkluzyjne pojmowanie omawianego prawa doskonale konweniuje z bardzo zróżnicowanym, czasem hybrydowym charakterem miejskich ruchów społecznych, które wypełniają puste znaczące „prawa do miasta” stosownie do taktycznego zapotrzebowania ${ }^{24}$.

nikiem partykularnej, bezpośredniej walki antykapitalistycznej, z drugiej - wspierając się autorytetem Marksa i przywołując jego słowa na temat rewolucyjnego charakteru walki o skrócenie dnia roboczego - aprecjuje walki społeczne o charakterze reformistycznym. Dopełnia to przywołanym uniwersalizmem, by prawo do miasta traktować jako prawo człowieka. Źródła tego sposobu myślenia są co najmniej dwa. Pierwsze to oczywista fascynacja Lefebvrem, który jak nikt mu współczesny pojął potencjał wolności drzemiący w stosunkach miejskich. Powtarza to za nim zresztą Harvey - horyzont miasta traktując jako skalę najbardziej odpowiednią do społecznych eksperymentów i wyzwanie egalitarnego, sprawiedliwego społeczeństwa. Drugie źródło to paralelne, ale jednocześnie zbieżne zainteresowania problemem i teoriami sprawiedliwości społecznej. Ich wczesnym efektem jest zresztą ważna publikacja Harveya, Social Justice and the City, Athens-London 2009 [wyd. 1 1973]; zob. również tegoż, Stosunki klasowe, sprawiedliwość spoteczna i polityka różnicy, tłum. J. Alejski i in., „Praktyka Teoretyczna” 2012, nr 5, http://www. praktykateoretyczna.pl/PT_nr5_2012_Logika_sensu/15.Harvey.pdf. Za uwagę dotyczącą partykularnych i uniwersalnych roszczeń Harveya dziękuję Piotrowi Juskowiakowi. Problematyczność przywołanego uniwersalizmu (stopienia prawa do miasta z prawami człowieka) polega po części na jego nie do końca przezwyciężonym eurocentryzmie. Walka o prawo do miasta (przywołajmy tu raz jeszcze Lefebvre’owskie „życie po miejsku” ) jest bowiem częściowo prerogatywą, pochodną specyficznego, opartego na industrializacji modelu kapitalistycznej modernizacji i zasadza się na wykluczeniu tego, co „nie-miejskie”.

23 Oczywiście, Harvey intensywnie poszukuje antykapitalistycznych alternatyw. Ostatnio kluczowe są tu jego, wsparte autorytetem Olinor Ostrom i polemiczne wobec propozycji Hardta i Negriego, rozważania na temat idei „dóbr wspólnych" (commons); zob. D. Harvey, Analiza Rzeczy-Pospolitej, tłum. P. Juskowiak, A. Kowalczyk, „Praktyka Teoretyczna” 2011, nr 4, http://www.praktykateoretyczna.pl/PT_nr4_2011_Commonwealth/08.Harvey.pdf.

24 Co więcej, otwartość, którą tu podkreślamy, prowadzić może nawet do prób przechwyceń idei przez ruchy ksenofobiczne, antyemancypacyjne; zob. A. Vradis, Intervention - The Right against the City, http://antipodefoundation. org/2012/10/01/intervention-the-right-against-the-city. 
Nim przejdziemy do próby opisu specyfiki miejskich ruchów społecznych w Polsce, pomocne będzie odwołanie się do ich dynamiki rozwojowej w kontekście historycznym. Próby takiej systematyzacji podjęła się Margit Mayer ${ }^{25}$. Autorka ta, odwołując się do kluczowych zmian kontekstu gospodarczego i politycznego zachodzących w czasach powojnia, przede wszystkim na Zachodzie, próbuje zdefiniować kluczową dla nich zmienność w dwóch współzależnych wymiarach: strukturalno-ideologicznych ram działania miejskich ruchów społecznych oraz postępującej polisemiczności sloganu „prawa do miasta”. Co istotne, dynamika rozwojowa fenomenu miejskich ruchów społecznych pokrywa się często z trajektorią ewolucji tak zwanych nowych ruchów społecznych. Mayer dokonała ostatecznie następującej periodyzacji:

Lata sześćdziesiąte i siedemdziesiąte dwudziestego wieku - definiuje je przede wszystkim kryzys fordyzmu i jego miejskiego wymiaru, wcielanego w życie jako „strefowanie” miasta. To między innymi ów kryzys rodzi coraz szerszą świadomość opresyjnego charakteru racjonalności instrumentalnej, która z miasta czyni przestrzeń produkcji i obiekt nieegalitarnej konsumpcji. Poczucie zdehumanizowania stosunków społecznych w mieście, które inspiruje choćby Lefebvre’a, jest siłą napędową rodzącej się wówczas opozycji parlamentarnej. Polityka wychodzi na ulice, „dzieje się” bezpośrednio w przestrzeni publicznej, hasła takie jak "let's take the city!” są na porządku dziennym, ugrupowania „odzyskujące miasto” odwołują się bezpośrednio do ideowego zaplecza nieortodoksyjnego marksizmu (choćby włoskie ugrupowanie Lotta Continua), w ofensywie są działania oparte na akcji bezpośredniej i literalnym zawłaszczaniu przestrzeni, rozkwita ruch skłoterski ${ }^{26}$. To, można by rzec, „moment heroiczny” ruchu, którego apragmatyczna wyobraźnia „żądała niemożliwego" ${ }^{27}$.

25 M. Mayer, The 'Right to the City' in the Context of Shifting Mottos of Urban Social Movements, "City” 2009, vol. 13; M. Mayer, The "Right to the City” in Urban Social Movements, w: Cities for People, Not for Profit.

26 A. Corr, No Trespassing: Squatting, Rent Strikes and Land Struggles Worldwide, Cambridge, MA 1999; L. Owens, Cracking Under Pressure: Narrating the Decline of Amsterdam Squatters Movement, Amsterdam 2009.

27 Wskazywaliśmy na sytuacjonistyczne zakotwiczenie pierwotnych ruchów miejskich. Tak sytuację duchową i nadzieje lat sześćdziesiątych opisywał Raoul Vaneigem: „Ludzie całymi wiekami tkwili przed drzwiami toczonymi przez robaki i z coraz większą łatwością wiercili w nich szpilkami małe dziurki. Do wyważenia tych drzwi wystarczy już dziś lekkie pchnięcie. Za nimi wszystko się dopiero rozpocznie", R. Vaneigem, Rewolucja życia codziennego, tłum. M. Kwaterko, Gdańsk 2004, s. 215. 
Lata osiemdziesiąte dwudziestego wieku naznacza defensywa „neoliberalna” (roll-back neoliberalization), której źródłem jest kryzys naftowy drugiej połowy lat siedemdziesiątych i stagflacja. To te zjawiska rodzą „thatcheryzm” i „reaganomikę”, zaś ich główną cechą są działania oparte na destrukcji - demontażu instytucji społecznych państwa dobrobytu. Prowadzi to do odradzania się „starych” problemów, związanych ze wzrostem nierówności społecznych oraz ideologiczną ofensywą strategii prywatyzacyjnych. Rodzi to nie tylko „nową” strukturę własności, ale restytuuje indywidualistyczny „prywatyzm obywatelski” oraz definiuje posesywizm i indywidualizm „klasy średniej” jako prawomocną ideologię panującą. Lata osiemdziesiąte to jednocześnie moment w którym dochodzi do wyczerpywania się energii utopijnych z dwóch poprzednich dekad, ruchy społeczne, w tym miejskie, ulegają instytucjonalizacji i częściowej kolonizacji (choćby niemieccy „Zieloni” ). Polityka protestu zastąpiona jest zinstytucjonalizowanymi formami działania, ma wówczas miejsce wybuch „trzeciego sektora”, kluczowymi aktorami stają się NGO'sy. Postulaty antysystemowe zastępowane są raczej logiką reformy i małych kroków, językiem ekspertyzy i prawa. Dochodzi do swoistej funkcjonalizacji, w ramach której to „siły społeczne” najlepiej definiują niedomagania systemu. Instytucjonalizacja i częściowa kolonizacja odnajduje swój wyraz w nawiązaniu relacji miedzy reprezentantami „trzeciego sektora” i władzami lokalnymi, wspierającymi reformistyczne inicjatywy miejskich aktywistów. Lata osiemdziesiąte to też czas rozwidlenia w ramach ruchu miejskiego. Dotyczy to również ruchu skłoterskiego: $\mathrm{z}$ jednej strony mamy do czynienia z jego kontynuacją, z drugiej zaś rozpoczyna się instytucjonalizacja skłotów jako „centrów socjalnych” czy „ośrodków kultury”.

Lata dziewięćdziesiąte dwudziestego wieku to moment ofensywy neoliberalnej (roll-out neoliberalization), której pole zostało przygotowywane w poprzedniej dekadzie. Następuje wzmocnienie tendencji z lat osiemdziesiątych oraz ich "globalizacja”. Antysystemowe siły społeczne są w „defensywie”, zaś ich wyobraźnia spętana do pewnego stopnia zaklęciem: there is no alternative. Jego efektem jest osłabiona dynamika działań ruchów społecznych i ich raczej defensywny charakter ${ }^{28}$.

28 Punktem kulminacyjnym jest erupcja ruchu alterglobalistycznego, zwanego też „ruchem ruchów” bądź „ruchem parasolowym”, z uwagi na jego inkluzyjny i hybrydowy charakter oraz niejednoznaczność związaną z tym faktem - wszak „innej globalizacji” w jego ramach domagali się również prawicowi, antykapitalistycznie zorientowani radykałowie. Z dzisiejszej perspektywy ruch alterglobalistyczny oceniany jest jako swoista dramatyzacja napięć i gwałtowana reakcja na „społeczny bezruch" lat dziewięćdziesiątych. Jego głównym problemem było to, że w obliczu 
Alterglobalizm przegrał miedzy innymi dlatego, że wyszedł od uniwersalnej krytyki systemu, nie potrafił jednak w żaden sposób zaproponować powszechnej w sensie praktycznym alternatywy. Między innymi ten fakt doprowadził do ograniczenia „ambicji” działań i poszukiwania alternatyw w bardziej lokalnych kontekstach. Ofensywa neoliberalna uderzyła też w ruch skłoterski: z jednej strony doszło do likwidowania licznych skłotów, z drugiej strony ich instytucjonalizacja posunięta została tak daleko, że skłoting i alternatywne style życia z nim związane poczęto wpisywać w logikę rozwojową „miasta kreatywnego”29.

Początek dwudziestego pierwszego wieku zdefiniowany został wyraźnie jako kryzys neoliberalizmu. Oznacza on zarówno kryzys podstawowych instytucji systemu kapitalistycznego, jak również coraz bardziej powszechny kryzys wiary w słuszność radykalnej, wolnorynkowej ideologii rodem $\mathrm{z}$ lat osiemdziesiątych i dziewięćdziesiątych ubiegłego stulecia. Nie przekłada się on jednak cały czas na żadną spójną i uniwersalną narrację definiującą realne alternatywy wobec „tu i teraz”.

W efekcie przegranej (albo też defensywy) alterglobalizmu, ruchy społeczne zorientowały się silniej w kierunku lokalizmu, w pewnej mierze przepracowując jego postulat "glokalizmu”. Miasto na powrót zostało zdefiniowane jako podstawowa i jednocześnie efektywna arena działań. Z ideą „prawa do miasta” coraz częściej współwystępują koncepty „sprawiedliwości przestrzennej” (Edward Soja) ${ }^{30}$ czy „demokracji miejskiej" (Mark Purcell) ${ }^{31}$.

Perspektywa Mayer, jako że ma w pewnej mierze charakter „rozważań wtrąconych”, wymaga krótkiego uzasadnienia. Jej przydatność polega moim zdaniem na tym, że - uogólniając długą tradycję powojennego „miejskiego buntu” - pozwala pokazać tło i uwypuklić „krótką historię" polskich ruchów miejskich (czy też ruchów społecznych wyrastających z kontrkulturowego pnia w ogóle). Strukturalne procesy

jednego, względnie spójnego „NIE!” nie wypracował wiążących strategii systemowych alternatyw. Na jego gruzach oraz ze świadomością mielizn, na które ruch wkraczał, wykształciły się liczne pomniejsze ruchy społeczne, między innymi o miejskim charakterze. Zob. P. Kingsnorth, One No, Many Yeses, London 2004.

29 Jednym z klasycznych przykładów jest Amsterdam. H. Pruijt, Squatters in the Creative City: Rejoinder to Justus Uitermark, "International Journal of Urban and Regional Research" 2004, vol. 28, no. 3; J. Uitermark, The Co-optation of Squatters in Amsterdam and the Emergence of a Movement Meritocracy: A Critical Reply to Pruijt, "International Journal of Urban and Regional Research" 2004, vol. 28, no. 3 .

30 E.W. Soja, Seeking Spatial Justice, Minneapolis 2010.

31 M. Purcell, Recapturing Democracy: Neoliberalization and the Struggle for Alternative Urban Futures, New York-London 2008. 
i kontrprocesy, które u Mayer trwają niemal pięć dekad, „cierpliwie” formowały różnorodną, również zmienną w czasie praxis ruchów protestu i reformy oraz - nierzadko - również ich funkcjonalizację i kolonizację. Trwały jednak relatywnie długo i dokonywały się w dalece bardziej uspołecznionym otoczeniu instytucjonalnym (struktury welfare state).

Polski z kolei eksperyment z radykalną wersją ideologii liberalnej i uruchomione na początku lat dziewięćdziesiątych procesy „stabilizacji systemu kapitalistycznego" to nie tylko przecież pozbawiony jakichkolwiek mechanizmów buforowych demontaż realnego socjalizmu, ale również „zamknięcie dyskursywne”, tryumf ideologii TINA. Prowadziło to do licznych napięć społecznych, nierzadko w łatwy sposób obnażało dysfunkcjonalność nowych reguł gry, co skutkowało pojawieniem się sił społecznych o charakterze reformatorskim i/lub kontestatorskim $^{32}$. Te ruchy społeczne, którym możemy przydać miano „miejskich”, pojawiły się na arenie społeczeństwa obywatelskiego w Polsce relatywnie późno, około dekadę temu. Od razu jednak objawiły swoją specyfikę. Rychło zogniskowały w sobie wszystkie te tendencje, o których wspomina w opisie ewolucji ruchów miejskich Mayer. Są udaną repliką tendencji i form rozwojowych ruchów miejskich Zachodu. W pewnym sensie można patrzeć na to jak na kolejny refleks procesów modernizacji $\dot{r}$ la polonaise. Aktywne w polskich miastach są zatem ruchy neoanarchistyczne, lokatorskie, ugrupowania mieszczańskie, organizacje pozarządowe rozmaitej proweniencji, wreszcie różnorakie mniej sformalizowane inicjatywy oddolne. Zatem mimo różnic w doświad-

Patchwork łączy jedno - dość mgliste

(wobec wielości roszczeń) i polisemiczne wykrzyknienie „prawa do miasta”. Być może, jeśli ufać intuicjom Harveya, również

w Polsce toczy się w chwili obecnej walka o to, kto napełni puste znaczeniem czeniu historycznym, wypracowane w trakcie pięciu dekad ewolucji (przede wszystkim) zachodniej kontrkultury formy miejskiego protestu okazały się przydatne również w Polsce. Patchwork łączy jedno - dość mgliste (wobec wielości roszczeń) i polisemiczne wykrzyknienie „prawa do miasta”. Być może, jeśli ufać intuicjom Harveya, również w Polsce toczy się w chwili obecnej walka o to, kto napełni puste znaczeniem.

\section{Miejskie ruchy społeczne w Polsce}

Zreasumujmy: miejskie ruchy społeczne w Polsce mają, po pierwsze, dość krótką historię (działają w kraju bez tradycji kontrkultury ${ }^{33}$ oraz

32 Zob. P. Żuk, Spoteczeństwo w dziataniu: Ekolodzy, feministki, sktotersi. Socjologiczna analiza nowych ruchów spotecznych w Polsce, Warszawa 2001.

33 Pisząc o „braku tradycji kontrkultury”, mam na myśli brak ruchów protestu zbieżnych z tymi, jakie dziś kojarzymy z dziedzictwem kontrkultury lat sześćdziesiątych czy też mitycznym rokiem 1968 (czyli przede wszystkim ruchami w Niemczech, Francji i Stanach Zjednoczonych, częściowo też we Włoszech czy 
długo tłumionej „kultury protestu” ${ }^{34}$ ); po drugie, funkcjonują w silnie $\mathbf{z}($ neo)liberalizowanym otoczeniu ideologicznym, na które odpowiedzią nie jest w żaden sposób wyobraźnia wspólnotowa, a raczej tradycjonalizm i konserwatyzm. Mają wreszcie dość mimetyczny charakter, w swym naśladowczym charakterze zaś wpisują się w logikę polskiej „mimetycznej modernizacji” ${ }^{35}$. Polskie ruchy miejskie stają więc dziś przed bardzo podobnymi dylematami „tożsamościowymi”, jak te, które towarzyszą miejskim ruchom społecznym zarówno w Europie, jak i poza jej granicami. Zaznaczyły też swoją obecność na przestrzeni ostatniej (mniej więcej) dekady, objawiły się w Polsce w podobnej panoramie zróżnicowań do tej, która konstytuowała się poza granicami Polski w ciągu mniej więcej czterech, pięciu dekad ${ }^{36}$.

Wydaje się wobec tego, że - zważając na wielość podmiotów działających na miejskiej arenie - można próbować skategoryzować głównych aktorów odwołujących się do postulatu „prawa do miasta” i logikę ich działań w następujący sposób:

1) ruchy neoanarchistyczne $e^{37}$,

Wielkiej Brytanii). Nie podzielam tu więc optymistycznego poglądu Immanuela Wallersteina, że protesty w Polsce, Czechosłowacji czy Meksyku były tą samą postacią „ideologicznej rewolucji” w systemie-świecie; zob. I. Wallerstein, S. Zukin, 1968 - Rewolucja w systemie światowym: Tezy i pytania, tłum. A. Ostolski, „Krytyka Polityczna” 2004, nr 6, s. 112-125. Podobnego utożsamienia mitu „maja 1968” i polskiego „marca 1968” próbuje też zresztą dokonać Adam Michnik; zob. tegoż, Moje pokolenie, mój bunt, w: Rewolucje 1968, Warszawa 2008, s. 5-6.

34 Owa „kultura protestu”, przez lata tłumiona, która wybuchła podczas „karnawału Solidarności”, miała jednak inny charakter niż kontrkulturowe ruchy antysystemowe wywodzące się z lat sześćdziesiątych oraz wszystkie te ruchy społeczne, które nawiązywały do ich logiki działania. Silniejszy nacisk kładła bowiem na tożsamość narodową oraz religijną, silniej zakorzeniona też była w logice działania „starych ruchów społecznych”. Zob. D. Ost, Klęska „Solidarności”: Gniew i polityka w postkomunistycznej Europie, Warszawa 2005; D. Ost, Klasy spoteczne to mit!: O klasach spotecznych, meandrach polskiej transformacji, kondycji związków zawodowych i lewicy, „Nowa Krytyka” 2011, nr 26-27, s. 401.

35 Symbolicznym wyrazem owego modernizacyjnego mimetyzmu są słowa Henryka Domańskiego: „Naszym celem jest Zachód”, H. Domański, Polska klasa średnia, Wrocław 2002, s. 8. Obsesję Zachodu i potrzebę egzorcyzmowania niezmodernizowanego „Wschodu w nas” dobrze charakteryzuje też artykuł Michała Buchowskiwego; tegoż, Widmo orientalizmu w Europie: Od egzotycznego Innego do napiętnowania swojego, „Recykling Idei” 2008, nr 10, s. 98-107.

36 Vide przywoływana periodyzacja autorstwa Margit Mayer.

37 Używając określenia neoanarchistyczne chcę podkreślić przeniesienie punktu ciężkości z opozycji wobec „klasycznej” władzy państwowej w kierunku władzy ekonomicznej, zatem silniejszy nacisk, niźli miało to miejsce w tradycyjnym 
2) ruchy lokatorskie,

3) „obywatelskie środowiska mieszczańskie” („ruchy mieszczańskie”),

4) organizacje trzeciego sektora - przede wszystkim NGO'sy, niekiedy realizujące w swoich działaniach logikę quasi-NGO’sów.

Zdaje się też, że można wskazać pewne tendencje do wewnętrznych afiliacji: aktorzy identyfikowani jako ruch neoanarchistyczny i lokatorski tworzą jedno ze skrzydeł, zbliżając się jednocześnie do tych klasycznych koalicji politycznych, które w literaturze przedmiotu zostały określone m.in. jako „ruchy ludzi biednych” ${ }^{38}$. Wyraźna jest w ich wypadku antykapitalistyczna retoryka, często inklinująca kwestionowanie własnościowych podstaw kapitalizmu. Jądrem konfliktów społecznych, w które zaangażowani są reprezentanci ruchu neoanarchistycznego i lokatorskiego, jest określony ład własnościowy, w „nowokapitalistycznej” Polsce oparty na sakralizacji własności prywatnej ${ }^{39}$. Niekiedy działania polegają na testowaniu elastyczności systemu (czasowe przechwycenia określonych przestrzeni, skłoting przestrzeni o niejasnej sytuacji własnościowej), czasem przyjmują postać konfliktów społecznych, w których centralną kwestią jest problem prywatnej własności (kwestia mieszkaniowa, blokady antyeksmisyjne, „czyszczenie kamienic” ) i próba jej desakralizacji. Narrację można w tym wypadku cały czas prowadzić z perspektywy konfliktowej, odwołując się do Engelsowskiej genezy idei „prawa do miasta”.

Aktorzy definiowani jako wyraziciele „etosu mieszczańskiego” są z kolei bliżsi logiki działania „trzeciego sektora” ${ }^{40}$. Krytyka antysystemowa przyjmuje tu najczęściej postać krytyki nadbudowy - przede wszystkim

ruchu anarchistycznym (a która to logika wyradzała w ramach antypaństwowych uniesień ideologii anarchokapitalistycznej), na tendencje antykapitalistyczne i zagrożenia ze strony kapitału.

38 F.F. Piven, R.A. Cloward, Poor People's Movement:. Why They Succeed, How They Fail, New York 1979.

39 Pojęcie własności jest w Polsce dość kłopotliwe. Po pierwsze, sprowadzane jest przede wszystkim do kategorii formalno-prawnych, nie zaś socjologicznoekonomicznych, po drugie zaś, samą własność utożsamia się z pewnym jej typem - własnością prywatną. Poza formalizm i redukcjonizm wykraczają liczne studia Stanisława Kozyra-Kowalskiego oraz Jacka Tittenbruna; zob. również P. Pluciński, Tytut prawny, posiadania, korzystanie - kontrowersje wokót socjologicznej teorii wtasności, „Ruch Prawniczy, Ekonomiczny i Socjologiczny” 2007, nr 3.

40 Polskie ruchy miejskie, co jest być może ich „chorobą dziecięcą”, jak wskazuje część badaczy i samych aktywistów, tworzą swoistą „magmę”. Stapiają się, innymi słowy, w jednolitą całość pomimo różnorodności. Zob. K. Pobłocki, Magma ruchów miejskich, http://publica.pl/teksty/magma-ruchow-miejskich. 
nieracjonalności, stronniczości czy antyobywatelskiego charakteru działań władz lokalnych, zaś próby „odzyskiwania miasta” są próbami przede wszystkimi walki politycznej (vide demokracja miejska), nie zaś oporu przeciwko instytucjom ekonomicznym. Środowiska te często skupiają się też na kwestiach estetyzacji miasta czy też prac nad większą funkcjonalnością miejskiej przestrzeni ( „napraw sobie miasto” ). Podejmowana przez nie niekiedy walka o partycypację (choćby budżetową) jest świadomą walką o korektę systemu. Nieobecna jest w tym wypadku krytyka fundamentów ładu i krytyka antykapitalistyczna dokonywana w kategoriach redefinicji podstaw systemu gospodarczego. W tym wypadku z kolei trudno przekładać logikę działań aktywistów na język konfliktowy, bliższa jest im tu zdecydowanie perspektywa funkcjonalna, czasem spod znaku funkcjonalizacji konfliktu ${ }^{41}$. Zresztą, część reprezentantów przywoływanych środowisk dość świadomie redefiniuje to, czym „prawo do miasta” miałoby być współcześnie, nacisk kładąc na jego silną pragmatyzację. Doskonale oddaje to wypowiedź Lidii Makowskiej - jednocześnie gdańskiej radnej i miejskiej aktywistki:

Co jest naszym celem? Czy dążenie do wspólnego marksistowskiego języka, czy raczej usprawnienie i uspołecznienie miasta? W moim przekonaniu ten drugi cel jest ważniejszy. Dlatego wydaje mi się, że na poziomie teoretycznym jak najbardziej powinniśmy czytać i analizować Harveya i np. Marksa w kontekście miejskim, natomiast w praktyce trzeba przyjąć inną strategię $e^{42}$.

\section{Od neoanarchizmu do ruchów lokatorskich}

Mimo że „miejska (r)ewolucja” wybuchła w Polsce pod koniec pierwszej dekady dwudziestego pierwszego stulecia, jej początków możemy doszukiwać się jeszcze w latach dziewięćdziesiątych ubiegłego wieku, przede wszystkim w kręgach neoanarchizmu czy też szerzej pojmowanej kultury alternatywnej.

Początek lat dziewięćdziesiątych ubiegłego wieku to moment powstawania w Polsce pierwszych skłotów ${ }^{43}$. Idea skłotingu w sposób

41 Źródeł takiej analizy możemy doszukiwać się w klasycznym ujęciu Simmla, później Cosera. Analiza empiryczna dokonywana w tym duchu obecna jest między innymi w: C.S. Sunstein, Sprzeciw w życiu spoteczeństw, tłum. J.S. Kugler, Warszawa 2006.

42 Jaki bunt? Jakich miast?, s. 11.

43 Początki polskiego skłotingu to skłoty przy ul. Oławskiej we Wrocławiu i ul. Kilińskiego w Łodzi. Żywym symbolem jest działający do dziś przy ul. Pu- 
najbardziej bezpośredni nawiązuje do pierwotnej energii lat sześćdziesiątych i strategii bezpośredniego „zawłaszczania miasta” („let’s take the city!”). To ze środowisk kontrkulturowych wywodzi się też szybko przeszczepiona na grunt polski idea reclaim the street (ewoluująca choćby w kierunku „masy krytycznej”) ${ }^{44}$. Środowiska neoanarchistyczne jako pierwsze podnosiły w Polsce postulaty budżetu obywatelskiego ${ }^{45}$. Wreszcie, to omawiane środowisko jeszcze pod koniec lat dziewięćdziesiątych wprowadzało postulaty socjalne jako imperatywy polityki publicznej na szczeblu lokalnym, niejako antycypując obecne, nabrzmiałe problemy strukturalne (wycofywanie się władzy lokalnej z roli dostarczyciela dóbr i usług „konsumpcji zbiorowej” - przede wszystkim mieszkalnictwa czy edukacji; „,pełzająca” gentryfikacja) ${ }^{46}$.

Jeszcze w latach dziewięćdziesiątych wyobraźnia polskiego ruchu neoanarchistycznego była uwięziona w ramach niemal wyłącznie antypaństwowego imaginarium (być może to jeszcze echo antysystemowego etosu lat osiemdziesiątych). Na przełomie wieków doszło jednak do silnej redefinicji tożsamościowej. Ma ona dwa źródła. Pierwsze, o charakterze politycznym, to rosnąca świadomość relatywnie niskiego wpływu na procesy oficjalnej, parlamentarnej polityki, pociągająca za sobą ryzyko nadmiernej marginalizacji i gettoizacji polityki oddolnej. Drugie to fala gwałtownej neoliberalizacji, w ramach której władza państwo-

ławskiego poznański „Rozbrat”. Historię polskiego skłotingu piszą też: „Twierdza” w Warszawie, gdańska „Rzeźnia”, wrocławski „Rejon 69”, gliwicki „Krzyk” czy białostockie „De Centrum”.

44 W działalność środowisk neoanarchistycznych wpisana jest bowiem bardzo silnie - definiująca etos wszelkich ruchów alternatywnych jeszcze od lat sześćdziesiątych - strategia czasowego zawłaszczania przestrzeni, traktowanej jako zasób wspólnotowy. Powszechnym punktem odniesienia jest tu idea tymczasowych stref autonomicznych Hakima Beya, czyli przestrzeni, w których zawiesza się reguły „stanowionego porządku" i ustanawia autonomiczne reguły, por. H. Bey, Tymczasowa strefa autonomiczna i inne eseje, tłum. I. Bojadżijewa, J. Karłowski, Kraków 2006.

45 Ruchy neoanarchistyczne wprowadzały do obiegu ideę budżetu partycypacyjnego, zanim jeszcze przebiła się ona do głównego nurtu polityki, stając się postulatem NGO'sów, niekiedy wręcz socjotechniką władzy lokalnej. Zob. R. Górski, Bez państwa: Demokracja uczestnicząca w dziataniu, Kraków 2007.

46 Pod koniec lat dziewięćdziesiątych powołano do życia Porozumienie Społeczne „Poznań Miasto Dla Ludzi”, którego główna ideą jest program miasta egalitarnego: „Poznań miastem nie dla eksmisji na bruk ludzi biednych [...], nie dla wyprzedaży i przejmowania przez prywatnych »właścicieli« mieszkań komunalnych [...], nie dla polityki władz lokalnych, która preferuje biznes i inwestycje nieuzgadniane z mieszkańcami [...], nie dla hipermarketów, centrów biznesu, banków i ulic zakorkowanych trującymi wszystkich samochodami”, cyt. za R. Antonów, Pod czarnym sztandarem: Anarchizm w Polsce po 1980 roku, Wrocław 2004, s. 340. 
wa staje się nierzadko mniej efektywna niż władza ekonomiczna kluczowych graczy gospodarki globalnej. Oba te procesy, nakładając się na siebie, doprowadzają do tego, że ruch neoanarchistyczny wyraźniej definiuje „nowego” wroga, stając się przy tym zdecydowanie antykapitalistyczny. Redefiniuje on przy tym przestrzeń działania, skuteczności poszukując na gruncie lokalnym, miasto zaś jako „idea polityczna” jest do tego idealnym gruntem. Tym bardziej, że na fali procesów urbanizacyjnych to właśnie w miastach najwyraźniej ogniskują się procesy związane z akumulacją kapitału, przekształcając miasto $\mathrm{w}$ „maszynkę do robienia pieniędzy" ${ }^{47}$.

Dokonując tej redefinicji, ruch neoanarchistyczny zachowuje z jednej strony przywiązanie do swoich tradycyjnych strategii działania politycznego, jakimi są: retoryczna antysystemowość (konsekwentny dyskurs, którego podstawą jest dyskusja na temat własności jako fundamentalnej instytucji społecznej), konfrontacyjność, wydzieranie systemowi „stref autonomicznych”, ostatecznie - kiedy to konieczne czy uzasadnione - logika akcji bezpośredniej (direct action). Z drugiej jednak strony, redefinicja tożsamościowa ruchu neoanarchistycznego wzbogacona jest o ewolucję strategii działania, przede wszystkim jego lekką pragmatyzację. Zaczyna on bowiem coraz szerzej wykorzystywać strategie legalistyczne jako narzędzia walki antysystemowej, traktując prawo jako instytucję, w ramach której można dokonywać strategicznych przechwyceńn ${ }^{48}$. Zgodnie z duchem lettrystycznego détournement, legalizm ów ma jednak charakter przygodny, w pewnym sensie „makiaweliczny”.

$\mathrm{O}$ istotnym znaczeniu środowisk neoanarchistycznych w kontekście ich „miejskości” niech wreszcie świadczy fakt, że to właśnie one poczęły „animować” odradzający się latach dziewięćdziesiątych ruch lokatorski. Dla przykładu - to krakowscy działacze Federacji Anarchistycznej już wtedy protestowali przeciwko podwyżkom czynszów czy eksmisjom. Kilka lat później identyczne działania zaczęli podejmować anarchiści poznańscy ${ }^{49}$. Najszybciej działania zinstytucjonalizowane podjęli działacze warszawscy (choćby w ramach kampanii „Mieszkanie prawem - nie towarem" czy w ramach współpracy z Warszawskim Stowarzyszeniem Lokatorów) ${ }^{50}$. W roku 2011, w reakcji na upowszech-

47 Zob. D. Harvey, Bunt miast, s. 50-101

48 Być może jest to efekt ożywionych relacji z ruchem lokatorskim.

49 R. Antonów, Pod czarnym sztandarem, s. 340.

50 Szersze omówienie tych zagadnień dla lat wcześniejszych: zob. m.in. P. Ciszewski, Obrońcy praw lokatorów, „Przegląd Anarchistyczny” 2008/2009, nr 8, s. 77-82; Warszawskie Stowarzyszenie Lokatorów, „Przegląd Anarchistyczny” 2008/2009, nr 8, s. 83-89. 
niający się proceder „czyszczenia kamienic” powstało przy współpracy z poznańskimi środowiskami neoanarchistycznymi Wielkopolskie Stowarzyszenie Lokatorów. W latach 2012-2013 podobne działania stymulują aktywiści krakowscy. Alians z ruchem lokatorskim jest w pewnym sensie zgodny z logiką uwspólniania wroga, którym został kapitał i zagrożenia płynące ze strony władzy ekonomicznej ${ }^{51}$.

Szczególnie dobrze widać to w kontekście zaangażowania w miejską politykę mieszkaniową, społeczną i kooperację z ruchami lokatorskimi. Mimo że te ostatnie nie wysuwają postulatów stricte radykalnych (nie podnoszą na przykład idei „strajku czynszowego” ), ich „rewolucjonizm” polega, identycznie jak w wypadku ruchu neoanarchistycznego, na kwestionowaniu i próbach redefinicji „uświęconych” instytucji społecznych, przede wszystkim własności. Walka antysystemowa, jakkolwiek najczęściej przebiegająca w przestrzeni dyskursywnej, ewentualnie walk legalistycznych o charakterze defensywnym (obrona praw lokatorów) i bezpośredniej działalności antyeksmisyjnej, oparta jest na kwestionowaniu instytucjonalnego staus quo i żądania jego rewizji w kierunku instytucjonalnego pluralizmu (choćby konstrukcji ładu opartego na społecznej współwłasności). Ruch neoanarchistyczny, szczególnie w kontekście sojuszu z ruchem lokatorskim sam przeszedł głęboką przemianę: od strategii radykalnych, opartych na działaniu bezpośrednim i taktyce protestu, czasem opartego na użyciu przemocy, ewoluował w kierunku stosowania taktyk „uzasadnionego obywatelskiego nieposłuszeństwa" w myśl których przechwytuje na własny użytek logikę systemową (język ekspertyz społecznych, język prawa), zaś w wypadku ich niepowodzenia wspiera je akcją bezpośrednią.

Dochodzimy tu do paradoksu. Mimo par excellance miejskiego charakteru działań (łatwo uzgadnialnego z materialistycznym pojmowaniem problemów miejskich zidentyfikowanych przez Engelsa i Lefebvre’a), mimo konstytuowania działań z zakresu miejskiej „sfery kontrpublicznej” 52 i kluczowego przeświadczenia o zakotwiczeniu „kwestii miejskiej” w „gospodarczej bazie społeczeństwa" ${ }^{53}$, spora część środowisk neoanarchi-

51 Vide slogan: „Miasto to nie firma!”.

52 Jako sferę kontrpubliczną rozumiem tu wytwarzanie „kontropinii” opinii publicznej poza dyskursem oficjalnym, między innymi poprzez konstrukcję alternatywnego wobec dominującego obiegu informacyjnego i wydawniczego, szerzej - dyskursywnego. Zob. m.in. publikacje: J. Urbański, Globalizacja a konflikty lokalne, Poznań 2002; tegoż, Odzyskać miasto: Samowolne osadnictwo, sktoting, anarchitektura, Poznań 2005; zob. również wydawnictwo ciągłe: „Przegląd Anarchistyczny", szczególnie numery: 8, 9, 10, 11, 13.

53 Zob. J. Urbański, Co to sa problemy miejskie?: Po Kongresie Ruchów Miejskich, http://www.rozbrat.org/publicystyka/aktywizm/2517-co-to-sa-problemymiejskie-po-kongresie-ruchow-miejskich. 
stycznych i alternatywnych konsekwentnie abstrahuje od sloganu „prawa do miasta”, nie używając go jako kluczowej kategorii organizacji rzeczywistości, w której działa ${ }^{54}$. Podsumowując, całokształt przedsięwzięć i konsekwencja ruchu neoanarchistycznego, jego coraz silniejsza pozycja prowadzą oczywiście do sytuacji, w której część efektów jego działań staje się dla ładu społecznego funkcjonalna - jednak tylko na poziomie funkcji ukrytych.

\section{Od „nowych mieszczan” do logiki NGO’sów}

Jakkolwiek krytyczny namysł nad miastem w Polsce i praktyka rodzimych miejskich ruchów protestu zapoczątkowana została w latach dziewięćdziesiątych, to same pojęcia „prawa do miasta” i „miejskich ruchów społecznych” obecne są w polskiej rzeczywistości, a co za tym idzie i w dyskursach akademickim i publicystycznym, relatywnie krótko. Pierwszą siłą społeczną, która zaczęła używać tych pojęć „autodefinicyjnie”, było poznańskie Stowarzyszenie (pierwotnie: Porozumienie Społeczne) „My-Poznaniacy”. Powstało ono jako zrzeszenie nieformalne w listopadzie 2007 roku, zaś 7 maja 2008 roku zostało zarejestrowane w KRS jako stowarzyszenie. To wyrosłe początkowo z logiki „ruchów protestu” 55 , po części też z doświadczeń politycznych (choćby z „Zielonych 2004”), środowisko ${ }^{56}$ stosunkowo szybko stało się dość silnym ruchem miejskim, z ambicjami politycznymi ${ }^{57}$. „My-Poznaniacy” niejako antycypowali „miejską (r)ewolucję”. Koniec pierwszej de-

54 Brak badań na ten temat. Można jednak postawić hipotezę (inspirowaną nieformalnymi rozmowami z częścią reprezentantów poznańskiego środowiska neoanarchistycznego), że to celowa strategia dystynkcji. Pojęcia "prawa do miasta” jako politycznego sloganu używa bowiem część środowisk, od których kręgi neoanarchistyczne się dystansują. Dochodzi wiec do paradoksu, że podmioty zmiany społecznej, które mogłyby przywoływać interesujący nas slogan w jego pierwotnym, konfliktowym kontekście, dystansują się od niego i wracają do retoryki tradycyjnej, oddolnej samoorganizacji.

55 Zob. L. Mergler, Poznań konfliktów, Poznań 2008.

56 Dość szczególne było i jest też pokoleniowo [ „My-P było zakładane przez zupełnie inne pokolenie (pamiętające Solidarność i PRL), niż pozostałe ruchy miejskie w większości polskich miast”, zob. K. Nawratek, Koniec ruchów miejskich?, wpis nr 711, http://krzysztofnawratek.blox.pl/html, oraz społecznie tworzyli je nie tylko, ale również właściciele nieruchomości czy prywatni przedsiębiorcy (zob. P. Pluciński, Przeciwko dzikiej urbanizacji, „Przegląd” 2001, nr 30, s. 49).

57 W Stowarzyszeniu doszło w pierwszej połowie 2013 roku do rozłamu. Jedną z najciekawszych analiz tego problemu zaproponował do tej pory Krzysztof Nawratek; zob. tegoż, Koniec ruchów miejskich? 
kady dwudziestego pierwszego stulecia to moment, kiedy miasto staje się „ideą polityczną”, zaś w większości dużych i średnich miast wyrastają „ruchy miejskie” ${ }^{8}$. Do części z nich rychło zaczęła być przykładana kategoria „nowych mieszczan” ${ }^{9}$.

Niezbędnych jest w tym momencie kilka słów komentarza do przywołanej właśnie kategorii. Sami „nowi mieszczanie” nie konstytuują jednego odrębnego bytu o charakterze klasowym czy stratyfikacyjnym - są swoistą hybrydą kulturową, wspólnotą „stylu życia po miejsku”, z naciskiem na estetyzację przestrzeni, jakość życia towarzyskiego i stowarzyszeniowego w mieście, szeroką i dobrze rozwiniętą ofertę kulturalną. Część „nowych mieszczan” jest zainteresowana podejmowaniem starań o takie właśnie miasto. O ile jednak przywoływanie pojęcie, tak samo jak kategoria „ruchy mieszczańskie”, budzi pewne wątpliwości, możemy przypisać mu pewne intuicje. O ile trudno charakteryzować „mieszczański” (drobnoburżuazyjny?) charakter ruchów miejskich poprzez przypisanie określonej pozycji społecznej i własnościowej ich aktywistom ${ }^{60}$, czyli zastosować klasyczne kategorie socjologicznej analizy klasowej, można próbować definiować ich mieszczański status poprzez wartości ${ }^{61}$, które realizują ${ }^{62}$. Być może więc „nowi mieszczanie” to ci, którzy cechują się relatywnie stabilną pozycją w strukturze społecznej, szczególnie w wymiarze ekonomicznym, mogąc dzięki temu redystrybuować część posiadanej nadwyżki (czasu, energii) w kierunku kulturowo sprofilowanej aktywności społecznej w mieście. Kluczowe jest jednak to, że ze strony środowisk mieszczańskich nie płyną żadne impulsy delegitymizujące obecny system gospodarczy.

58 Dobre wyobrażenie o wielości działających ruchów i organizacji miejskich daje przegląd uczestników II Kongresu Ruchów Miejskich w Polsce, który miał miejsce w październiku 2012 roku w Łodzi: http://kongresruchowmiejskich. pl/?page_id=349.

59 P. Kubicki, Nowi mieszczanie w nowej Polsce, Warszawa 2011, http:// www.instytutobywatelski.pl/wp-content/uploads/2011/05/Ksie\%CC\%A8ga_ mieszcz.pdf.

60 Mają one po prostu zbyt złożony charakter, poza tym brakuje badań i danych pozwalających na twarde wnioski co do pozycji klasowej aktywistów.

61 Socjologiczne pojmowanie wartości to traktowanie ich jako tych obiektów (idealnych lub materialnych), na które jednostki nakierowują swoje działanie.

62 Taka perspektywa nie jest odosobniona. Dokładnie te same problemy występują w innych krajach środkowoeuropejskich, między innymi w Bułgarii. Zob. Ł. Pancewicz, Walcząc o dobro wspólne: Od ruchów oburzonych do miejskich rewolucji, http://publica.pl/teksty/walczac-o-dobro-wspolne-od-ruchow-oburzonych-do-miejskich-rewolucji. 
W pewnym sensie moglibyśmy odwołać się tu do wpływowej teoriomodernizacyjnej koncepcji Ronalda Ingleharta i jego teorii wartości: tradycyjnych, materialistycznych i postmaterialistycznych. Zakładając, że jesteśmy w momencie, mimo ciągłego zakotwiczenia w tradycjonalizmie i materialnym niepełnym zaspokojeniu, kiedy to aktywizm społeczny staje się coraz mniej awangardowy ${ }^{63}$, zaś w realizację szeroko pojmowanych wartości postmaterialistycznych zaczynają angażować coraz szersze segmenty polskiego społeczeństwa ${ }^{64}$.

W tym kontekście intuicja o „mieszczańskim” charakterze części ruchów miejskich jest może nieco bardziej klarowna, co nie oznacza, że nie pozostaje częściowo problematyczna, bowiem wykrzyknienie „miejskiej rewolucji” cały czas nastręcza trudności. Korekty zastanego ładu społecznego na poziomie miasta, jakimi zainteresowani są aktywni obywatele, nie mają w żadnej mierze rewolucyjnego charakteru.

Większa jest też w tym wypadku podatność na „przechwycenia” czy też kolonizację krytyki społecznej. Wyraźna jest wreszcie jej funkcjonalność zarówno na poziomie funkcji jawnych, jak i ukrytych. Nikt inny bowiem lepiej niż sami obywatele nie zdefiniuje kluczowych punktów krytycznych w systemie, przyczyniając się raczej do wzrostu sprawności systemu niż do jego rewolucyjnej zmiany. Ta ostatnia bowiem wymaga przemiany (lub choć na poziomie retorycznym: żądania przemiany) kluczowych instytucji systemu - te zaś zawsze definiowane są jako instytucje gospodarcze. Innymi słowy - mamy tu raczej do czynienia z działalnością reformatorską, pozwalającą systemowi ewoluować, nie zaś „rewolucjonizować”.

Miejskie środowisko to też częściowo naturalna przestrzeń dla aktorów, jakimi są NGO'sy (lub wręcz QUANGO’sy). Mają one rozmaity charakter - są tak zróżnicowane, jak kłopotliwa pod tym względem kategoria tak zwanego trzeciego sektora. Cały czas brak miarodajnych badań pozwalających oszacować skalę zjawiska absorpcji środków i logiki (jak wyznaczyć granicę miedzy działalnością społeczną a parago-

63 Forpocztą „postmaterializmu” w Polsce były w latach dziewięćdziesiątych relatywnie wąskie kręgi związane z ruchem skłoterskim, neoanarchistycznym czy kontrkulturowymi odmianami feminizmu; zob. P. Żuk, Spoteczeństwo w dziataniu; P. Pluciński, Kolonizacja świata życia a nowe ruchy spoteczne: Postmaterializm po polsku, [w:] Wtasność i interesy $w$ dobie transformacji ustrojowej, red. J. Tittenbrun, Poznań 2006.

64 Rodzi się oczywiście pytanie: czy możliwe jest spełnienie się nadziei socjologów, jakie żywili dekadę czy dwie temu na upowszechnienie się społecznego aktywizmu, na zerwanie ze „społecznym bezruchem” ? Nie sposób jednak odpowiedzieć na nie w tym miejscu. Zob. Czy spoteczny bezruch?: O spoteczeństwie obywatelskim i aktywności we wspótczesnej Polsce, red. M. Nowosielski, M. Nowak, Poznań 2006. 
Zdaje się więc, że postulat „miejskiej rewolucji" wypisany

na sztandarach „nowych mieszczan” jest raczej ewidentną postacią systemowej ewolucji, o ile tylko „prawo do miasta” w ich rękach staje się prawem do miasta raczej estetycznego,

funkcjonalnego, atrakcyjnego kulturalnie, niż miasta egalitarnego i eksperymentującego z fundamentami modusu kapitalistycznego spodarczą?) oraz efektywności ich wykorzystania ${ }^{65}$. Mamy też niekiedy do czynienia z personalnym i instytucjonalnym „krzyżowaniem się" ścieżek miejskich aktywistów i działalności opartej na absorpcji publicznych środków. Wskazać bowiem można podmioty, które dość wyraźnie i efektywnie działają w obu logikach: będąc efektywnym grantobiorcą oraz platformą aktywizmu zarazem ${ }^{66}$.

Zdaje się więc, że postulat „miejskiej rewolucji” wypisany na sztandarach „nowych mieszczan” jest raczej ewidentną postacią systemowej ewolucji, o ile tylko „prawo do miasta” w ich rękach staje się prawem do miasta raczej estetycznego, funkcjonalnego, atrakcyjnego kulturalnie, niż miasta egalitarnego i eksperymentującego $\mathrm{z}$ fundamentami modusu kapitalistycznego.

\section{W poszukiwaniu kryteriów rozróżnień}

Mimo prób zdefiniowania rozmaitych podmiotów, jak podkreśliłem, nie sposób chyba zbudować apriorycznie, w ramach „wymiarowania początkowego", żadnej wiążącej typologii. Nie oznacza to jednak wcale, że nie należy poszukiwać kryteriów rozróżnień, opartych na upraszczającym rzeczywistość myśleniu typowo-idealnym, ułatwiających typizację a posteriori. Innymi słowy, podtrzymuję nadzieję, że pogłębione badania umożliwią dokonanie bardziej klarownych rozróżnień.

Dokonując namysłu nad możliwymi kryteriami rozróżnień, proponuję następujące wymiary:

1) Przedmiot krytyki społecznej

Czy kwestionowane są fundamentalne instytucje społeczne (ład własnościowy), czy też instytucje wobec nich wtórne (prawo, polityka parlamentarna i lokalna, instytucje polityczne i społeczne, dostęp do dóbr i usług o charakterze publicznym)?

2) „Polityczność” versus ,apolityczność”

Czy działanie w przestrzeni pozaparlamentarnej (oraz poza przestrzenią lokalnej, oficjalnej, partyjnej polityki) jest „polityczne” czy „nie- „lub też „apolityczne”? Tradycja badań nad klasyczną opozycją pozaparlamentarną wskazuje na totalny charakter polityczności (przy-

65 Zob. R. Drozdowski, Lepsza sfera publiczna - bezdyskusyjny postulat pod dyskusję, [w:] O miejskiej sferze publicznej: Obywatelskość i konflikty o przestrzeń, red. M. Nowak, P. Pluciński, Kraków 2011.

66 Przykładem może tu służyć część środowiska skupionego wokół Fundacji im. Henryka Krzeczkowskiego i czasopisma „Res Publica Nowa” czy też Fundacji im. Stanisława Brzozowskiego i „Krytyki Politycznej”. 
pomnijmy hasło maja 1968 roku: „prywatne jest polityczne”). Część aktywistów miejskich na poziomie retoryki postuluje „apolityczność” swojego zaangażowania. Kluczowe jest tu rozważenie kwestii polityczności: jej związków z neutralnością, interesem ideologicznym lub też ewentualnym mirażem neutralności i „fałszywą świadomością”.

3) Horyzontalizm („mit płaskich struktur”?) versus „instytucjonalizacja”

Część reprezentantów ruchów społecznych, szczególnie ci przywiązani do klasycznej wizji „nowych ruchów społecznych”, podkreśla swoje przywiązanie do działalności oddolnej, do etosu horyzontalizmu i „demokracji wiecowej”, z kolei inni traktują je jako niezdrowy, nieefektywny, wręcz szkodliwy, bo paraliżujący skuteczne działanie mit, traktując struktury hierarchiczne jako konieczność i warunek brzegowy skutecznego działania. Jest to jednocześnie pierwszy z wymiarów pragmatyzacji społecznej wyobraźni i strategii działania ruchów społecznych.

4) Legalizm versus uzasadnione „obywatelskie nieposłuszeństwo”

Część reprezentantów ruchów społecznych, szczególnie ci wyraźnie antyinstytucjonalnie nastawieni, podejrzliwie i z niechęcią traktowała strategie legalistyczne. Z czasem jednak, również wśród reprezentantów autonomistycznie zorientowanych ruchów rozpowszechniło się przekonanie o użyteczności narzędzi formalnoprawnych ${ }^{67}$. Przez część ruchów traktowane są one jako jedyna możliwa ścieżka społecznego protestu czy wpływu (nie ma tu działań poza prawem), przez część z kolei są uzupełniane - w wypadku niepowodzenia pierwotnie aplikowanych działań o charakterze legalistycznym - działaniami o charakterze wtórnym - odwołującymi się do (uzasadnionego) obywatelskiego nieposłuszeństwa, sporadycznie też przekraczającymi barierę, jaką jest stosowanie przemocy. Stopień zastosowania strategii legalistycznych konstytuuje moim zdaniem drugi z wymiarów pragmatyzacji społecznej wyobraźni i strategii działania ruchów społecznych.

4. Mainstreaming versus gettoizacja (ewentualne „wytwarzanie sfery kontrpublicznej”). Dotyczy przede wszystkim sposobów obecności w sferze publicznej. Strategia mainstreaming polega na specyficznej walce dyskursywnej: walce o „widzialność”, czyli konsekwentnym i stałym uczestnictwie w ramach przekazów mediów głównego nurtu, staraniach o „dobrą obecność”, wreszcie - niekiedy na przesuwaniu dyskursywnych granic (na przykład następująca retoryka: „to nie my jesteśmy radykalni, to porządek, przeciwko któremu występujemy,

67 Problem ten: interpretacja prawa do miasta jako „zawłaszczenia” oraz jako „uznania prawnego”, jest obecnie jednym z naczelnych dylematów w ramach dyskusji o przyszłości ruchów miejskich, zob. M. Mayer, The "Right to the City" in Urban Social Movements, w: Cities for People, Not for Profit, s. 71-77. 
jest opresyjny”, „to on wytwarza nasz "radykalizm«” ). Z drugiej strony pozostaje gettoizacja oraz zamknięcie dyskursywne. Może być ono jednak pochodną decyzji samych podmiotów autowykluczających się z ładu medialnych przedstawień, może być też efektem zwyczajnego wykluczenia z porządku dyskursu. W jednym i drugim wypadku pozostaje jeszcze reakcja polegająca na kreacji „kontrdyskursów” i kreacji „sfery kontrpublicznej”.

\section{Zamiast podsumowania}

O ile konstytuujące się Polsce miejskie ruchy społeczne tworzą (przywołaną tu za Kacprem Pobłockim) „magmę”, są cały czas niejednoznaczne, o tyle można mieć nadzieję na jej krystalizację. Stawiane są już wprawdzie hipotezy o uwiądzie polskich ruchów miejskich ${ }^{68}$, sowa Minerwy wylatuje jednak zawsze o zmierzchu. Zanim ogłosimy ich śmierć, muszą one rzeczywiście zejść ze sceny. Z dzisiejszej perspektywy nie wiemy, w jakim kierunku pójdą, jakie strategie ostatecznie przyjmą, jak zredefi-

Z dzisiejszej perspektywy nie wiemy, w jakim kierunku pójdą, jakie strategie ostatecznie przyjmą, jak zredefiniują

kluczowe idee, do których się odwołują,

czy dadzą się połknąć,

skolonizować, czy też oprą się pokusom systemowej inkluzji, ile „ruchu” pozostanie w nich jako "ruchach" społecznych, wreszcie

- czy rzeczywiście przetrwają? niują kluczowe idee, do których się odwołują, czy dadzą się połknąć, skolonizować, czy też oprą się pokusom systemowej inkluzji, ile „ruchu” pozostanie w nich jako „ruchach” społecznych, wreszcie - czy rzeczywiście przetrwają? Jeśli jednak jakiekolwiek myślenie normatywne jest w tym względzie pożądane - należy mieć nadzieję na trwanie sił społecznych walczących o bardziej sprawiedliwe i egalitarne stosunki społeczne.

Być może, w konsekwencji podjętej próby heurystycznych rozróżnień i poszukiwania ich kryteriów, zaproponowane tu kategoryzacje okażą się pomocne, by ową „magmę" lepiej poznać, rozumieć i wyjaśnić.

68 K. Nawratek, Koniec ruchów miejskich? 
PRZEMYSŁAW PLUCIŃSKI - Absolwent Wydziału Nauk Społecznych UAM oraz Wydziału Ekonomii Uniwersytetu Ekonomicznego w Poznaniu, adiunkt w Zakładzie Historii Gospodarczej Instytutu Historii UAM. Interesuje się teorią socjologiczną i teorią krytyczną społeczeństwa, socjologią miasta, dynamiką ruchów społecznych oraz tak zwaną kulturą alternatywną. Autor artykułów w czasopismach specjalistycznych ( „Ruch Prawniczy, Ekonomiczny i Socjologiczny”; „Przegląd Zachodni”; „Kultura Popularna”; „Kultura Współczesna”; „Nowa Krytyka”, „Hegel-Jahrbuch” ) oraz opracowaniach zbiorowych, przekładów z zakresu krytycznej teorii społecznej oraz szczypty publicystyki. Radykałowie wymyślają mu od liberałów, liberałowie zarzucają socjalizm. Za młodu zaczytywał się w Abramowskim. Ofiara kapitalizmu kulturowego: kocha muzykę, która zastępuje mu powietrze.

\section{Dane adresowe autora: \\ Przemysław Pluciński \\ Zakład Historii Gospodarczej \\ Instytut Historii UAM \\ Ul. św. Marcin 78 \\ 61-809 Poznań \\ e-mail: plucin@amu.edu.pl}

\section{Cytowanie:}

P. Pluciński, Miejskie (r)ewolucje. Radykalizm retoryki a praktyka reformy, „Praktyka Teoretyczna” 3(9)/2013, „Praktyka Teoretyczna” nr 3(9)/2013, http://www.praktykateoretyczna.pl/PT_nr9_2013_Po_kapitalizmie/ 06.Pluciński.pdf (dostęp dzień miesiąc rok)

Author: Przemysław Pluciński

Title: Urban (r)evolutions. Radical rhetoric versus reformist praxis

Abstract: The paper deals with the idea of ??the right to the city (RTTC), one of the leading ideologies of contemporary emancipatory politics. It also focuses on social actors (mainly Polish urban social movements) as the RTTC users and deals with the problem how urban activists use the idea in everyday political praxis. The right to the city is analysed with respect to the Laclau's notion of an "empty signifier", that is, as an element which depends on the interpretation put on it in the pragmatics of social struggles. Furthermore, the article examines the fact of consistent functionalization of the RTTC idea. The initially Marxian concept of revolutionary origins is now becoming increasingly reformist and is being used mainly as a popular political label.

Keywords: the right to the city, social movements, urban social movements, marxism, social change, revolution, reformism. 